\title{
Root Characteristics of Different Rice Varieties under Two Different Hydrological Situations as Influenced by Methods of Establishment in Wet Season
}

\author{
Priyanka Das*, J. M. L. Gulati and Sarthak Pattanayak
}

Dept. of Agronomy, College of Agriculture, Orissa University of Agriculture and Technology, Bhubaneswar, Odisha (751 003), India

\section{Article History}

Manuscript No. AR1631

Received in $29^{\text {th }}$ June, 2016

Received in revised form $25^{\text {th }}$ September, 2016

Accepted in final form $4^{\text {th }}$ October, 2016

\section{Correspondence to}

${ }^{*} E$-mail: priyankapinky2408@gmail.com

\section{Keywords}

Aerobic, anaerobic, root length, root spread

\begin{abstract}
Field experiment was conducted on Agronomy Main Research Farm, Department of Agronomy, Orissa University of Agriculture and Technology on kharif 2015 taking six crop establishment methods and three varieties under aerobic (Non puddled-Non flooded) condition while 5 establishment methods and three varieties under anaerobic (Puddled-flooded) condition in observation strip to study on root traits of different rice varieties under two hydrological situations of aerobic and anaerobic condition revealed that, all the root traits recorded higher values with aerobic transplanting $\left(20 \times 20 \mathrm{~cm}^{2}\right)$ and modified SRI $\left(20 \times 20 \mathrm{~cm}^{2}\right)$ under aerobic and anaerobic conditions, respectively. Aerobic $\left(25 \times 25 \mathrm{~cm}^{2}\right)$ and conventional transplanting recorded higher root-length ratio of 3.82 and 2.55 under aerobic and anaerobic situations respectively. The ratio of root length to root dry weight was however, higher with direct seeding (29.83) and conventional planting (22.2) under similar situations aerobic rice. On an average, across the methods, aerobic condition registered an increase of $13.2 \%$ in mean root length over anaerobic one $(27.2 \mathrm{~cm})$ whereas, the extent of increase in mean root spread and root dry weight was 3 and $5.9 \%$ under an aerobic condition over aerobic condition with corresponding absolute values of $26.7 \mathrm{~cm}$ and $121 \mathrm{~g}$. Pyari measured longest roots $(43.34 \mathrm{~cm})$ under aerobic and highest root dry weight $(2.73 \mathrm{~g}$ hill $\left.^{-1}\right)$ under anaerobic condition while Naveen recorded maximum horizontal spread $(19.3 \mathrm{~cm})$ under an aerobic and root volume $(28.0 \mathrm{cc})$ under aerobic conditions. Root length-spread ratio (6.28) and root length-root dry weight ratio (25.60) was highest with Naveen under aerobic situation.
\end{abstract}

\section{Introduction}

Increasing scarcity of water has threatened the traditional rice cultivation practices all over the World. The situation is further aggravated by drought, global warming, methane emission, adverse climatic changes, over-pumping of ground water causing aquifer resources to decline and the high 'cost' of water (Tuong and Bouman, 2003). Irrigation for agriculture consumes $2 / 3^{\text {rd }}$ of the World's fresh water and rice alone consumes more than $50 \%$ of the water used for irrigation in Asia. Overexploitation of groundwater has caused serious problems in many parts of India including Haryana and Punjab; groundwater tables have dropped on average by $0.5-1.0 \mathrm{~m}$ $\mathrm{y}^{-1}$ in states of India (Bouman and Tuong, 2001). Rice is a profile user of water which water required 3000-5000 litres of water to produce one $\mathrm{kg}$ of grain which is 2 to 3 times than any other cereal crops such as wheat and maize (IRRI, 20009). Compared with traditional lowland rice cultivation, water inputs in aerobic rice were less than 50\% (only 470-650 mm), water productivities were $64-88 \%$ higher, gross returns were lower by $28-44 \%$ and labour use were $55 \%$ lower. Aerobic rice is an attractive option to farmer where water is too scarce to grow low land rice. Roots are the important plant organ that can alter the plants performance by way of exploring unit volume of soil through its density, enhancing plant's ability to explore new soil parts through its duration and rate of extension, and by utilising different resources through its penetration deep into the soil besides providing encourage to plant. Growth and development of root depends upon many factors like soil texture, structure, its nutrient water holding capacity and overall its micro environment. A developed root system leads to better crop growth and performance. Rice does differ genetically in its rooting pattern but it also varies with the change of soil environment. Kato and Okami (2011) opined that rice performance in aerobic culture might be 
improved through genetic manipulation that promotes lateral root branching and rhizometric as well as deep rooting. The development of root traits also depends upon mode and age of establishment. In recent years, few water saving techniques are being advocated for raising a rice crop (Tuong et al., 2005). Knowledge of rooting habit of promising genotypes under such environments is of interest as the study is pre-requisite for development of proper agronomic practice. Considering this, the root characteristics of different rice cultivars were studied in two hydrological situations where the crop was established through different methods during wet season.

\section{Materials and Methods}

A field study was carried out at Agronomy Main Research Farm, Department of Agronomy, College of Agriculture, Orissa University of Agriculture and Technology, Bhubaneswar (India) during wet season of 2014 in split plot design with three replications. Eighteen treatment combinations under aerobic un puddle condition consisting of six establishment methods ( $\mathrm{M}_{1}$-direct seeding with $20 \mathrm{~cm}$ row to row spacing, $\mathrm{M}_{2}$-Aerobic conventional rectangular transplanting at $20 \times 10 \mathrm{~cm}^{2}$ spacing with 2-3 seedling hill-1 ${ }^{-1} \mathrm{M}_{3}$-Aerobic square transplanting at $20 \times 20 \mathrm{~cm}^{2}$ spacing with 1 seedling hill-1 $\mathrm{M}_{4}$-Aerobic square transplanting at $25 \times 25 \mathrm{~cm}^{2}$ spacing with 1 seedling hill'-1, $\mathrm{M}_{5}-$ Aerobic square transplanting at $20 \times 20 \mathrm{~cm}^{2}$ spacing with 2 seedling hill ${ }^{-1}$ and $\mathrm{M}_{6}$-Aerobic square transplanting at $25 \times 25$ $\mathrm{cm}^{2}$ spacing with 2 seedling hill-1) were taken in main plot and three rice varieties $\left(\mathrm{V}_{1}\right.$-Naveen, $\mathrm{V}_{2}$-Hiranmayee and $\mathrm{V}_{3}$-Aerobic rice Pyari) were allotted to sub-plot. Another set of experiment as observation strip with same three varieties was also laid out under anaerobic puddle condition with five establishment methods such as conventional rectangular transplanting at $20 \times 10 \mathrm{~cm}^{2}$ spacing with 2-3 seedling hill-1 $\left(\mathrm{S}_{1}\right)$, square transplanting at $20 \times 20 \mathrm{~cm}^{2}$ spacing with 1 seedling hill $^{-1}\left(\mathrm{~S}_{2}\right)$, square transplanting at $25 \times 25 \mathrm{~cm}^{2}$ spacing with 1 seedling hill-1 $\left(\mathrm{S}_{3}\right)$, square transplanting at $20 \times 20 \mathrm{~cm}^{2}$ spacing with 2 seedling hill ${ }^{-1}\left(\mathrm{~S}_{4}\right)$ and square transplanting at $25 \times 25$ $\mathrm{cm}^{2}$ spacing with 2 seedling hill-1 $\left(\mathrm{S}_{5}\right)$. The soil of both the experimental site was sandy loam in texture at surface with $\mathrm{pH}$ 5.34 and 5.98 having organic carbon $0.44 \%$ and $0.40 \%$ and EC $0.151 \mathrm{dS} \mathrm{m}^{-1}$ and $0.163 \mathrm{dS} \mathrm{m}^{-1}$. The total available nitrogen, phosphorus and potassium under aerobic and anaerobic condition were $214.10,54.32$ and $110.12 \mathrm{~kg} \mathrm{ha}^{-1}$ and 286.0, 16.87 and $129.5 \mathrm{~kg} \mathrm{ha}^{-1}$, respectively. Nitrogen, phosphorus and Potassium @ 80-40-40 kg ha ${ }^{-1}$ were applied to all the plots through urea, DAP and MOP. Well decomposed FYM @ 5 $\mathrm{t} \mathrm{ha}^{-1}$ was incorporated into the soil at final ploughing. Full dose of $\mathrm{P}$ and $\mathrm{K}$ and $25 \%$ of $\mathrm{N}$ was applied at final ploughing/ puddling. Rest of $\mathrm{N}$ was applied in 2:1 ratio at tillering and panicle initiation stage, respectively. Crop during its growing period received a rainfall of $1348.7 \mathrm{~mm}$ in 78 rainy days. Crop was irrigated to supplement rainfall during the growth period. Seeds were directly sown in solid rows on well pulverised un-puddled soil as treatment ${ }^{-1}$ under $M_{1}$. On the same date dry nursery was prepared to raise the seedling for use in main experiment under aerobic transplanting as well as for observation strip (puddle anaerobic condition). For transplanting under aerobic (un-puddle) and anaerobic (puddle) condition, one seedling $\left(\mathrm{M}_{3}, \mathrm{M}_{4}\right.$ and $\mathrm{S}_{2}, \mathrm{~S}_{3}$ treatments) and two seedlings $\left(\mathrm{M}_{5}, \mathrm{M}_{6}\right.$ and $\left.\mathrm{S}_{4}, \mathrm{~S}_{5}\right)$ hill ${ }^{-1}$ at two leaf stage while for conventional transplanting $\left(\mathrm{M}_{2}\right.$ and $\left.\mathrm{S}_{1}\right) 2-3$ seedlings hill- $^{-1}$ at four leaf stage were transplanted under aerobic and anaerobic conditions, respectively. A pre soaking irrigation was provided to the well pulverised soil under aerobic condition to facilitate the transplanting. Root study was made through excavation method involving three hills and the observationon middle hill was taken. Root length-spread ratio and Root length-dry weight ratio was calculated as formulae given by Kato and Okami (2010); Kamath (1971).

\section{Results and Discussion}

Root length increased progressively upto 100 days after sowing (DAS) both under aerobic and anaerobic condition and decreased thereafter at harvest. On an average, across the methods, aerobic condition registered an increase of $13.2 \%$ in mean root length over anaerobic one $(27.2 \mathrm{~cm})$ whereas, the extent of increase in mean root spread and root dry weight was 3 and 5.9\% under anaerobic condition over aerobic condition with corresponding absolute values of $26.7 \mathrm{~cm}$ and $121 \mathrm{~g}$ (Table 1). Among the treatments, transplanting 2 seedlings at $25 \times 25$ $\mathrm{cm}^{2}$ spacing recorded the longest root $(32.5 \mathrm{~cm})$ under aerobic condition while transplanting at same spacing with 1 seedlings hill $^{-1}$ recorded the longest $(29.0 \mathrm{~cm})$ under anaerobic condition at 100 DAS (Table 2). The shortest root length was recorded under direct sowing condition which may be the result of severe competition due to more population unit ${ }^{-1}$ area. Aerobic condition measured long roots showing that roots grow longer in search of water under aerobic condition than the anaerobic. The results are in conformity with Sridhar et al. (2011).

Root spread also followed the same trend as that of length measuring widest at 100 days after sowing under both the conditions. However, transplanting 1 seedling hill-1 ${ }^{-1}$ at $20 \times 20$ $\mathrm{cm}^{2}$ spacing and 2 seedlings at $25 \times 25 \mathrm{~cm}^{2}$ spacing measured a spread of $27.9 \mathrm{~cm}$ and $28.2 \mathrm{~cm}$ under aerobic and anaerobic condition, respectively.

Irrespective of the treatments, rate of increase in all the root traits was the maximum between $25-50$ days after sowing. Length-spread ratio is a good measure of compactness ofroot system. Higher ratio was observed under aerobic condition at any stage of growth with higher values at initial period of crop 


\begin{tabular}{|c|c|c|c|c|c|c|c|c|c|c|}
\hline \multirow[t]{3}{*}{ Treatment } & \multicolumn{10}{|c|}{ Days after sowing } \\
\hline & \multicolumn{5}{|c|}{ Root length } & \multicolumn{5}{|c|}{ Root spread } \\
\hline & 25 & 50 & 75 & 100 & Harvest & 25 & 50 & 75 & 100 & Harvest \\
\hline $\mathrm{M}_{1}$ & 8.53 & 16.87 & 27.67 & 27.99 & 25.67 & 6.23 & 12.23 & 21.00 & 22.5 & 21.33 \\
\hline $\mathrm{M}_{2}$ & 6.13 & 15.87 & 28.83 & 29.33 & 27.40 & 4.13 & 10.53 & 23.30 & 24.33 & 22.00 \\
\hline $\mathrm{M}_{3}$ & 6.60 & 18.40 & 29.67 & 31.09 & 27.67 & 4.63 & 12.33 & 25.10 & 27.86 & 24.00 \\
\hline $\mathrm{M}_{4}$ & 6.67 & 18.00 & 30.03 & 31.50 & 28.03 & 4.53 & 14.10 & 25.00 & 27.00 & 25.00 \\
\hline $\mathrm{M}_{5}$ & 6.97 & 18.27 & 30.50 & 32.3 & 28.50 & 5.43 & 13.80 & 24.00 & 26.50 & 24.20 \\
\hline $\mathrm{M}_{6}$ & 6.73 & 18.80 & 30.90 & 32.5 & 28.90 & 4.30 & 14.60 & 25.00 & 27.23 & 24.80 \\
\hline \multicolumn{11}{|l|}{ Variety } \\
\hline $\mathrm{V}_{1}$ & 6.75 & 17.33 & 29.47 & 30.58 & 27.62 & 4.85 & 12.87 & 23.50 & 25.48 & 22.73 \\
\hline $\mathrm{V}_{2}$ & 7.28 & 17.87 & 29.67 & 30.82 & 28.17 & 4.85 & 13.12 & 24.75 & 26.75 & 24.54 \\
\hline $\mathrm{V}_{3}$ & 6.78 & 17.90 & 29.67 & 30.95 & 27.30 & 4.91 & 12.82 & 23.50 & 25.48 & 23.00 \\
\hline
\end{tabular}

$\mathrm{M}_{1}$ : Direct seeding with $20 \mathrm{~cm}$ row to row spacing; $\mathrm{M}_{2}$ : Aerobic conventional rectangular transplanting at $20 \times 10 \mathrm{~cm}^{2}$ spacing with 2-3 seedling hill' ${ }^{-1} ; \mathrm{M}_{3}$ : Aerobic square transplanting at $20 \times 20 \mathrm{~cm}^{2}$ spacing with 1 seedling hill-1; $\mathrm{M}_{4}$ : Aerobic square transplanting at $25 \times 25 \mathrm{~cm}^{2}$ spacing with 1 seedling hill-1; $\mathrm{M}_{5}$ : Aerobic square transplanting at $20 \times 20 \mathrm{~cm}^{2}$ spacing with 2 seedling hill-1 $\mathrm{M}_{6}$ : Aerobic square transplanting at $25 \times 25 \mathrm{~cm}^{2}$ spacing with 2 seedling hill ${ }^{-1} ; \mathrm{V}_{1}:$ Naveen; $\mathrm{V}_{2}:$ Hiranmayee; $\mathrm{V}_{3}$ : Aerobic rice Pyari

\begin{tabular}{|c|c|c|c|c|c|c|c|c|c|c|}
\hline \multirow{3}{*}{$\begin{array}{l}\text { Treat- } \\
\text { ments }\end{array}$} & \multicolumn{10}{|c|}{ Days after sowing } \\
\hline & \multicolumn{5}{|c|}{ Root length } & \multicolumn{5}{|c|}{ Root spread } \\
\hline & 25 & 50 & 75 & 100 & Harvest & 25 & 50 & 75 & 100 & Harvest \\
\hline $\mathrm{S}_{1}$ & 8.53 & 14.40 & 23.70 & 25.80 & 19.80 & 6.20 & 11.70 & 22.30 & 24.30 & 23.90 \\
\hline $\mathrm{S}_{2}$ & 10.30 & 18.40 & 26.70 & 27.80 & 23.00 & 7.90 & 16.40 & 24.80 & 26.80 & 26.33 \\
\hline $\mathrm{S}_{3}$ & 9.60 & 16.90 & 26.20 & 29.00 & 21.00 & 7.10 & 14.70 & 25.70 & 28.00 & 26.03 \\
\hline $\mathrm{S}_{4}$ & 9.10 & 18.10 & 25.80 & 26.80 & 21.50 & 7.80 & 15.20 & 25.00 & 27.50 & 25.57 \\
\hline $\mathrm{S}_{5}$ & 9.30 & 16.50 & 26.50 & 26.50 & 21.80 & 7.70 & 16.30 & 25.80 & 28.20 & 25.33 \\
\hline \multicolumn{11}{|l|}{ Variety } \\
\hline $\mathrm{V}_{1}$ & 10.30 & 16.70 & 26.20 & 27.30 & 19.80 & 7.70 & 14.60 & 24.40 & 26.70 & 24.62 \\
\hline $\mathrm{V}_{2}$ & 9.40 & 17.10 & 26.30 & 28.00 & 20.70 & 7.20 & 15.40 & 24.90 & 27.20 & 26.12 \\
\hline $\mathrm{V}_{3}$ & 8.30 & 16.90 & 24.90 & 26.24 & 18.70 & 7.20 & 14.60 & 24.70 & 26.98 & 25.56 \\
\hline
\end{tabular}

growth (25 DAS). Transplanting of 2 seedling at $25 \times 25 \mathrm{~cm}^{2}$ spacing recorded highest length: spread (1.57) under aerobic condition while under anaerobic condition, transplanting of 1 seedling at $25 \times 25 \mathrm{~cm}^{2}$ spacing recorded the highest of 1.35 . However, root length-dry weight ratio was not consistent in their trend under different situations and higher values were observed in between 25-50 and 75-100 DAS under both the situations. Similar trend was also noticed by Lenka and Gulati (2015).

Volume is the combined expression of root length and spread, and varies according to growing habit and habitat. Transplanting of 1 seedling at $25 \times 25 \mathrm{~cm}^{2}$ spacing recorded maximum root volume both under aerobic $(24.1 \mathrm{cc})$ and anaerobic $(31.4 \mathrm{cc})$ condition (Table 3). Direct sowing also recorded the higher volume $(24.01 \mathrm{cc})$ which might be due to the more number of plants unit ${ }^{-1}$ area. Root dry weight increased periodically upto 100 DAS and declined thereafter at harvest showing senescence and death of roots. Transplanting of 1 and 2 seedlings at $20 \times 20 \mathrm{~cm}^{2}$ and $25 \times 25 \mathrm{~cm}^{2}$ spacing, respectively recorded the maximum root dry weight of 115.16 $\mathrm{g} \mathrm{m}^{-2}$ under aerobic condition while transplanting of 1 seedling at $20 \times 20 \mathrm{~cm}^{2}$ spacing recorded the maximum dry weight of $122.83 \mathrm{~g} \mathrm{~m}^{-2}$ under anaerobic condition (Table 4). Initial period of crop growth is important where there was maximum 


\begin{tabular}{|c|c|c|c|c|c|c|c|c|c|c|}
\hline \multirow{3}{*}{$\begin{array}{l}\text { Treat- } \\
\text { ments }\end{array}$} & \multicolumn{10}{|c|}{ Days after sowing } \\
\hline & \multicolumn{5}{|c|}{ Root volume } & \multicolumn{5}{|c|}{ Root dry weight } \\
\hline & 25 & 50 & 75 & 100 & Harvest & 25 & 50 & 75 & 100 & Harvest \\
\hline $\mathrm{M}_{1}$ & 2.67 & 13.78 & 21.01 & 24.10 & 17.78 & 20.60 & 55.40 & 98.33 & 119.91 & 109.91 \\
\hline $\mathrm{M}_{2}$ & 2.28 & 12.54 & 19.45 & 23.60 & 16.53 & 19.01 & 55.87 & 84.78 & 108.94 & 102.39 \\
\hline $\mathrm{M}_{3}$ & 2.25 & 12.25 & 19.85 & 23.10 & 17.00 & 20.61 & 56.76 & 90.37 & 115.16 & 105.37 \\
\hline $\mathrm{M}_{4}$ & 2.38 & 12.50 & 18.5 & 24.10 & 16.50 & 18.49 & 58.72 & 93.12 & 113.90 & 105.33 \\
\hline $\mathrm{M}_{5}$ & 2.42 & 12.82 & 18.28 & 21.00 & 16.50 & 18.20 & 56.53 & 91.46 & 113.19 & 101.73 \\
\hline $\mathrm{M}_{6}$ & 2.46 & 12.90 & 19.00 & 22.90 & 17.00 & 16.50 & 49.10 & 101.45 & 115.16 & 109.10 \\
\hline \multicolumn{11}{|l|}{ Variety } \\
\hline $\mathrm{V}_{1}$ & 2.39 & 12.78 & 19.40 & 22.90 & 16.97 & 18.06 & 54.95 & 88.98 & 111.48 & 104.40 \\
\hline $\mathrm{V}_{2}$ & 2.39 & 12.78 & 19.33 & 22.83 & 16.91 & 19.80 & 55.78 & 99.58 & 120.45 & 106.94 \\
\hline $\mathrm{V}_{3}$ & 2.45 & 12.84 & 19.31 & 22.81 & 16.89 & 18.86 & 55.45 & 91.19 & 111.19 & 105.57 \\
\hline
\end{tabular}

\begin{tabular}{|c|c|c|c|c|c|c|c|c|c|c|}
\hline \multirow{3}{*}{$\begin{array}{l}\text { Treat- } \\
\text { ments }\end{array}$} & \multicolumn{10}{|c|}{ Days after sowing } \\
\hline & \multicolumn{5}{|c|}{ Root volume (cc) } & \multicolumn{5}{|c|}{ Root dry weight $\left(\mathrm{g} \mathrm{m}^{-2}\right)$} \\
\hline & 25 & 50 & 75 & 100 & Harvest & 25 & 50 & 75 & 100 & Harvest \\
\hline $\mathrm{S}_{1}$ & 6.30 & 24.50 & 25.30 & 30.30 & 23.16 & 31.14 & 71.33 & 98.67 & 121.25 & 104.14 \\
\hline $\mathrm{S}_{2}$ & 5.60 & 22.88 & 23.30 & 28.60 & 21.30 & 21.91 & 64.80 & 100.15 & 122.83 & 114.56 \\
\hline $\mathrm{S}_{3}$ & 5.80 & 23.3 & 26.31 & 31.40 & 21.70 & 32.21 & 66.45 & 99.14 & 120.00 & 108.51 \\
\hline $\mathrm{S}_{4}$ & 4.89 & 22.5 & 23.51 & 29.50 & 20.67 & 49.47 & 63.66 & 100.13 & 122.30 & 111.53 \\
\hline $\mathrm{S}_{5}$ & 9.96 & 18.51 & 23.00 & 28.13 & 20.93 & 43.68 & 70.62 & 106.01 & 118.74 & 100.91 \\
\hline \multicolumn{11}{|l|}{ Variety } \\
\hline $\mathrm{V}_{1}$ & 7.70 & 24.38 & 26.33 & 31.60 & 23.60 & 37.68 & 68.71 & 99.88 & 119.99 & 110.83 \\
\hline $\mathrm{V}_{2}$ & 7.28 & 21.39 & 23.35 & 28.69 & 20.62 & 32.93 & 64.25 & 96.24 & 116.35 & 105.86 \\
\hline $\mathrm{V}_{3}$ & 4.56 & 21.25 & 23.19 & 28.47 & 20.44 & 36.43 & 69.17 & 106.36 & 126.73 & 107.10 \\
\hline
\end{tabular}

percentage increase in different root characters under both hydrological situations. Transplanting of 2 seedlings at $20 \times 20$ $\mathrm{cm}^{2}$ spacing recorded the highest shoot: root (6.43) under aerobic condition while 1 seedling at $25 \times 25 \mathrm{~cm}^{2}$ recorded the highest (7.51) under anaerobic condition at harvest (Figure 1

Aerobic shoot:root

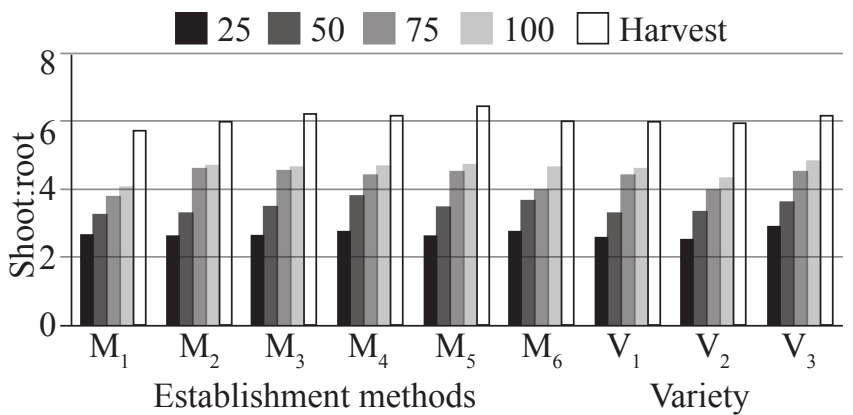

Figure 1: Shoot:root as influenced by establishment methods and variety under aerobic
$\& 2)$. Depth of root penetration and lateral spread are variety and environment dependent (Uphoof and Amiharisoa, 2007 and Kato and Okami, 2011). Higher values of other root traits under aerobic condition can be attributed to better aeration and less degeneration of roots (Lenka and Gulati, 2015).

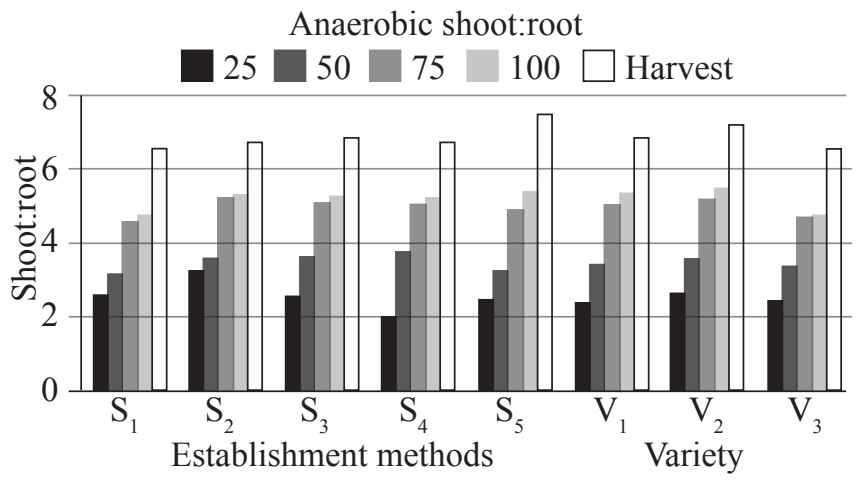

Figure 2: Shoot:root as influenced by establishment methods and variety under anaerobic condition 


\subsection{Effect of variety}

Among the varieties aerobic rice Pyari measured longest root of $30.95 \mathrm{~cm}$ under aerobic condition while medium duration variety Hiranmayee recorded the longest $(28.00 \mathrm{~cm})$ under anaerobic condition at 100 DAS. Variety Hiranmayee measured the maximum horizontal expansion both under aerobic $(26.75 \mathrm{~cm})$ and anaerobic $(27.20 \mathrm{~cm})$ condition at 75

DAS. Maximum volume of $22.83 \mathrm{cc}$ and $28.69 \mathrm{cc}$ was recorded by under aerobic and anaerobic condition, respectively. Variety Hiranmayee and Pyari recorded the maximum root dry weight of 120.45 and $126.73 \mathrm{~g} \mathrm{~m}^{-2}$ under aerobic and anaerobic condition, respectively. Aerobic variety Pyari recorded the highest shoot: root ratio (6.17) under aerobic condition while Hiranmayee recorded highest (7.18) under anaerobic condition at harvest. Similar varietal differences were also seen by Lenka and Gulati, (2015).

\section{Conclusion}

Roots are important part of plant system influenced largely by the genotypes and growing below ground environment. All the root traits recorded higher values with aerobic transplanting $\left(20 \times 20 \mathrm{~cm}^{2}\right)$ and modified SRI $\left(20 \times 20 \mathrm{~cm}^{2}\right)$ under aerobic and anaerobic conditions, respectively. Aerobic rice Pyari measured longest roots under aerobic and highest root dry weight under anaerobic condition while Naveen recorded maximum horizontal spread under anaerobic and root volume under aerobic conditions.

\section{References}

Bouman, B.A.M., Tuong, T.P., Field water management to save water and increase its productivity in irrigated rice. Agricultural Water Management 2001, 49(1),11-30.

Kato, Y., Okami, M., 2011. Root morphology, hydraulic conductivity and plant water relation of high yielding varieties grown under aerobic condition. Annals of Botany 108(3), 575-583.

Kamath, M.B., 1971. Classification of some wheat and paddy varieties according to root distribution. In: Proceedings of symposium on use of radioisotopes in agriculture and animal Husband Research. NRL, IARI, New Delhi, 296-637.

Kato, Y., Okami, M., Tazima, R., Fuzita, D., Kobayashi, N., 2010. Root response to aerobic conditions in rice estimated by comair root length scanner and scanner based image analysis, Field Crop Research, 118, 194-198.

Lenka, S., Gulati, J.M.L., 2015. Root traits of rice (Oryza sativa L.) varieties under two hydrological situations as influenced by different methods of establishments. Middle-East Journal of Scientific Research 23(6), 1204-1209.

Sridhar, C.J., Ramachandrappa, B.K., Kumarswamy, A.S., Gurumurthy, K.T., 2011. Effect of planting geometry and method of establishment on root traits and yield of rice. Karnataka Journal of Agricultural Sciences 24(2), 129-132.

Tuong, T.P., Bouman, B.A.M., Mortimer, M., 2005. More rice; less water-integrate approaches for increasing water productivity in irrigated rice-based system in Asia. Plant Production Science 231-241.

Tuong, T.P., Bouman, B.A.M., 2003. Rice production in water-scarce environments. In: Kijne J.W., Barker, R., Molden, D., (Eds.), water productivity in agriculture: limits and opportunities for improvement. UK: CABI Publishing, 53-67.

Uphoof, N., Amiharisoa, R., 2007. Root studies in aerobic rice genotypes. In: Water wise rice production, International Rice Research Institute, Manila: Philippines, 71-87. 